\title{
Flood Vulnerability Mapping Using Geographic Information System (GIS) in Gajah Wong Sub Watershed Yogyakarta
}

\author{
A. Ardiansyah ${ }^{1 *}$ and Dyah Respati Suryo Sumunar ${ }^{2}$ \\ ${ }^{1}$ Geography Education Master Program, Yogyakarta State University, Jl. Colombo No.1, \\ Karang Malang, Yogyakarta, 55281, Indonesia \\ 2Department of Geography Education, Yogyakarta State University, Jl. Colombo No.1, \\ Karang Malang, Yogyakarta, 55281, Indonesia \\ *Corresponding Author : ardiansyah.2016@student.uny.ac.id
}

Received 18 March 2019/ Revised 18 September 2019/ Accepted 23 November 2019/ Published 10 April 2020

\begin{abstract}
Gajah Wong Sub Watersheds frequently hit by floods which are potentially damaging. Therefore, a study on a flood vulnerability of the area is deemed necessary. This study aims to map floods vulnerability, to know the level and its spread in Gajah Wong Sub Watershed of Yogyakarta County Province by using Geographic Information System (GIS). The methods implemented in this study was weighting and scoring analysis and overlay of parameter attributes data of flood vulnerability framer, consisting of land use, slope of mountain, rainfall, soil type, geology, height of location and river buffer. Each parameter of flood vulnerability framer is classified based on the magnitude of effect towards flood vulnerability. The results of this study indicate that there were three levels of flood vulnerability in Gajah Wong Sub Watershed, i.e. low flood vulnerability of $338.34 \mathrm{Ha}$ (6.86\%), medium flood vulnerability level of 4,595.62 $\mathrm{Ha}(93.13 \%)$ and high flood vulnerability level of $0.76 \mathrm{Ha}(0.02 \%)$. Low flood vulnerability level is ditributed randomly to all areas of Gajah Wong Sub Watershed cover of Ngaglik Sub-district, Depok Sub-district, small part of Pleret Sub-district and was predominantly in Banguntapan Sub-district, an area with rainfall. Medium flood vulnerability areas dominated Gajah Wong Watershed. Meanwhile, high flood vulnerability level occupied small portion of the area and spread in the southern part of Pleret Sub-district which was taken as the area of River Buffer analysis.
\end{abstract}

Keywords: GIS; Gajah Wong; Sub Watershed; Yogyakarta.

\section{Introduction}

Climate change has seriously affected the environment and human life. Change in climate would contribute to increasing frequency and severity of disaster and cause flood ( $\mathrm{Jia}$ et al., 2016). Generally, flood is caused by natural and non natural factors. Flood occurs as a result of heavy rain effect and natural water channel having no capacity to collect water (Ramdhan et al., 2018). Area with lowland condition and near a river tends to have higher 
floods vulnerability (Kourgialas \& Karatzas, 2016). Flood disaster may have negative effects on social-economic, loss of human and properties, problems associated with health, and ecosystem functions (Sein \& Myint, 2016).

Gajah Wong Sub Watershed covers an area of $49.34 \mathrm{~km}^{2}$, consisting of three areas of district/city, namely, districts of Sleman, Yogyakarta City and Bantul which cover 9 areas of sub-districts, i.e. Pakem, Ngemplak, Ngaglik, Depok, Umbulharjo, Kota Gede, Gondokusuman, Bantul, and Pleret (Hartono, 2014). Observation results indicate the frequent occorrence of annual floods in Gajah Wong Sub Watershed, with some major floods which may occur twice a year. These frequently occurring floods were caused by overflow of Gajah Wong River and these have cause damages to houses and some other losses.

Flood is considered one of the most common natural disasters contributed to losses and damage to infrastructure and the environment (Santillan et al., 2016). Flood disasters carry serious implications for humans; hence, there is a crucial need to manage and determine areas having flood vulnerability (Stoica \& Iancu, 2011).

Vulnerability is associated with a condition determined by social, economical, and ecological factors or processes, resulting in higher vulnerability of people in dealing with hazard (Christiawan \& Wesnawa, 2014). Social factors include social conditions such as population density, sex ratio, poverty ratio, disability rate, and the ratio of vulnerable age groups. Economic factors include the condition of productive land area and gross regional domestic product (GRDP). Environmental vulnerabilities generally relate to land use conditions (BNPB, 2012).Vulnerability concept is generally associated with natural hazard, disaster and ecology (Beevers \& Strathie, 2016).

Knowledge and understanding of flood vulnerability are paramountly crucial for the government and people. Map is a good instrument to present data and information. Mapping areas with flood vulnerability interval is essential as it can be the basis for the government to make appropriate policy to prevent it. GIS provides support especially for policy and decision makers. Flood can be mapped by Attribute Analysis using weighing and scoring methodaiming at giving specific values to spatial data phenomena. This mapping activity aims at knowing the effects of components on flood vulnerability in Gajah Wong Watershed.

Geographic Information System (GIS) is an integrated software, designed specially to be used with geographic data to perform tasks of data processing comprehensively consisting of input, storage, retrieving and output of data with various analytical and descriptive types (Weng, 2010). Recent disaster analyses are inseparable from GIS and the role of remote sensing. The use of GIS with remote sensing combination can widely be used and applied to 
analyze disaster with provision of spatial data networks nationally and entirely (Manfré, 2012). With these attributes, GIS may be functional and may have positive impacts on human life. GIS can be an essential tool in decision making of sustainable development, because GIS provides information to decision making for spatial database and analysis (Suryantoro, 2009).

Previous related research stated that spatial databases include flood inventory, slope, flow power index (SPI), Topographic Wet Index (TWI), altitude, curvature, distance from rivers, geology, rainfall, Land Use / Cover (LULC), and types soil (Tehrany et al., 2014). Remote sensing is effective for analysing trends in environmental change related to biodiversity in recent years (Pettorelli et al., 2014). Lowland with 10-15\% slope and with a sewage disposal network is the most vulnerable to flooding (igović et al., 2017). Analysis related to geology and distance from the river using digital elevation models is most influential on reducing flood risk (Lee et al., 2017). The distance from the fault and the type of soil also greatly affects the level of flood vulnerability (Tehrany et al., 2017).

Previous studies did not examine flood vulnerability in karst and quarterly volcanic areas such as those in Yogyakarta. Therefore, this study carried out on watersheds with a combination of quarter volcanic land and karst land in the provincial capital contributes in this regard. This study aims to map the vulnerability of floods to know the level and its spread in Gajah Wong Sub Watershed of Yogyakarta County by using a Geographic Information System (GIS).

\section{Methods}

This is a descriptive quantitative study with the aims to disclose facts available accompanied by interpretation and analysis (Tika, 2005). This use of quantitative methods was mainly because data in this research is mainly attribute data that is dominated by numerical data.The data are used to carry out weighting, scoring and overlay analysis to produce flood vulnerability maps. This study aims to map flood vulnerability by viewing the level and its spread through results of flood vulnerability paramater data. This study aimed to provide reliable and accurate results.

Analysis by weighing, scoring and overlay are more popularly used today, especially related to the use of a Geographical Information System (GIS). Some government institutions such as Regional Development Planning Board, Public Work Office, Meteorological, Climatological, and Geophysical Agency often use this method to perform spatial analysis, especially related to natural disaster study. The methods used are easier and are compatible to use with varied parameter attributal data/variable that will be overlaid. However, this analysis 
also has weaknesses because it greatly depends on the availability, data update and paramater data generalisation process to be used. Hence, it can decrease the accuracy of a flood vulnerability data output yielded.

\section{$2.1 \quad$ Sites}

This study was conducted in Gajah Wong Sub Watershed of Yogyakarta County Province. Gajah Wong Sub Watershed is a part of Opak Watershed through three areas of Regency/City and nine sub-districts. This study was performed for three months from January through March 2018.

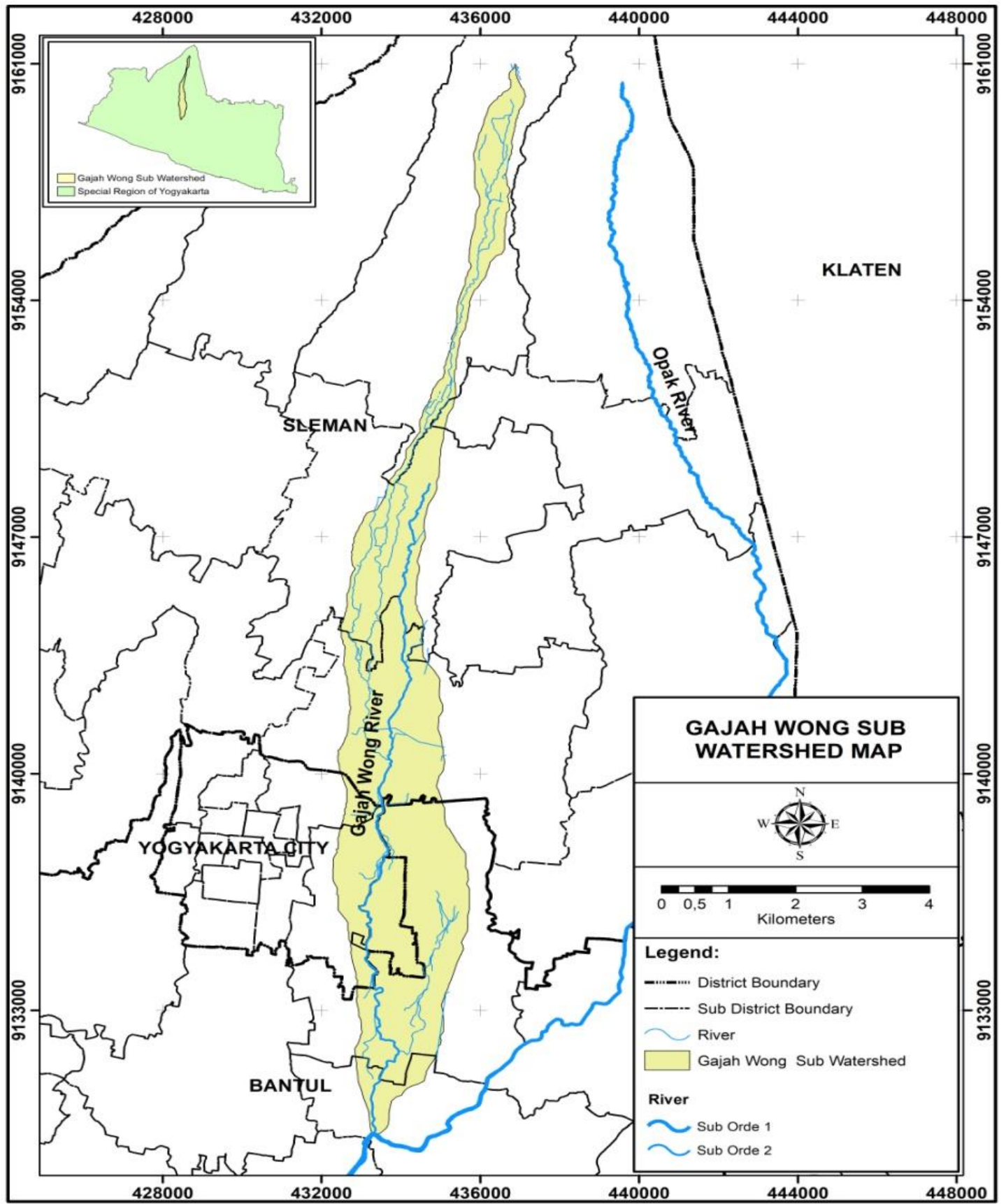

Figure 1. Map of Gajah Wong sub watershed 


\subsection{Data Source}

Data used in this study were secondary data collected from some institutions such as Development Planning Agency at Sub-National Level (BAPPEDA) available to GIS portal (sig.jogjaprof.go.id), Mlati Climatology Station (BMKG) and Center for Water Resources Management (BPSDA).

\subsection{Data Processing}

This study used weighing and scoring method with overlay technique of attribute data of each flood vulnerability arrangement parameter. Data obtained were then adjusted, reclassified and analysed to obtain final results in form of flood vulnerability map. Mapping of flood vulnerability needs some basic parameters/variables functioning as arrangement parameters. Flood vulnerability parameters in this study focuses on modified environmental vulnerability such as land use, slope inclination, rainfall, soil type, geology, location height and river buffer. Each of the parameters is rated for weighing and classification based on magnitude of effect on flood. The following are weighing and scoring of flood vulnerability parameter.

\subsubsection{Land Use}

Classification of land use is based on Indonesian National Standardisation Agency No. 7645/2010 with modification based on scale of 1:50,000 - 1:25,000 (SNI, 2010: 13-28). Previously, these data were tested for accuracy using confuse matrix method. Land use is classified into five criteria with the highest score of 15 and lowest score of 3.

Table 1. Weighing and scoring of land use

\begin{tabular}{|c|c|c|c|}
\hline Land Use & Value & Weight & Score \\
\hline $\begin{array}{l}\text { Reservoir, River, Swamp, Open } \\
\text { Land, Water Body, Pond, } \\
\text { Freshwater Pond }\end{array}$ & 5 & & 15 \\
\hline $\begin{array}{c}\text { Settlement, Industry, } \\
\text { Mixed Plantation, Pier, Port, Field }\end{array}$ & 4 & & 12 \\
\hline $\begin{array}{c}\text { Agriculture, Irrigation Fields, } \\
\text { Rainfed Rice Fields, yards, } \\
\text { Airports }\end{array}$ & 3 & 3 & 9 \\
\hline $\begin{array}{l}\text { Farm / Moor, Plantation, Shrub, } \\
\text { Grass / Empty Land, Graveyard }\end{array}$ & 2 & & 6 \\
\hline $\begin{array}{c}\text { Production Forest, Protection } \\
\text { Forest }\end{array}$ & 1 & & 3 \\
\hline
\end{tabular}


A.Ardiansyah and Dyah Respati Suryo Sumunar / GEOSI Vol 5 No 1 (2020) 47-64

\subsubsection{Slope Inclination}

Classification of slope inclination is based on Social Forestry and River Flow Zone Management Development-General Director's Decree No. P. 3/V-Set/2013 on River Flow Zone. Slope inclination is classified into five criteria, namely: flat, sloped, waved, steep, very steep. The highest score is 25 and lowest score is 5 .

Table 2. Weighing and scoring of slope inclination

\begin{tabular}{ccccc}
\hline Slope Inclination $(\%)$ & Criteria & Value & Weight & Score \\
\hline $0-8$ & Flat & 5 & & 25 \\
$>8-15$ & Sloped & 4 & & 20 \\
$>15-25$ & Waved & 3 & 5 & 15 \\
$>25-40$ & Steep & 2 & & 10 \\
$>40$ & Very Steep & 1 & & 5 \\
\hline
\end{tabular}

\subsubsection{Rainfall}

Data of rainfall are based on average rain/year for 14 years. Analysis used was inverse distance weighted (IDW) interpolation. Classification of rainfall are based on Social Forestry and River Flow Zone Management Development-General Director's Decree No. P. 3/VSet/2013 on River Flow Zone Characteristic Identification Guidance. Data of rainfall are classified into 5 criteria, namely: low, rather low, medium, high and very high. Highest score is 20 and lowest score is 4 .

Table 3. Weighing and scoring of rainfall

\begin{tabular}{cccc}
\hline Rainfall $(\mathrm{mm} /$ year $)$ & Value & Weight & Score \\
\hline $1500-2000$ & 1 & & 4 \\
$>2000-2500$ & 2 & & 8 \\
$>2500-3000$ & 3 & 4 & 12 \\
$>3000-3500$ & 4 & & 16 \\
$>3500-4000$ & 5 & & 20 \\
\hline
\end{tabular}

\subsubsection{Soil Type}

Classification of soil type is based on classification system issued by modified Farming Land Resource Research \& Development-Big Hall Head (Subardja, Ritung, Anda, Suryani \& Subandiono, 2014: 12-19). Soil type consists of Grumosol, Mediterranean, Latosol, Kambisol \& Alluvial, Regosol. Highest score is 10 and lowest score is 2 . 
A.Ardiansyah and Dyah Respati Suryo Sumunar / GEOSI Vol 5 No 1 (2020) 47-64

Table 4. Weighing and scoring of soil type

\begin{tabular}{lccc}
\hline \multicolumn{1}{c}{ Soil Type } & Value & Weight & Score \\
\hline Grumosol & 5 & & 10 \\
Mediterranean & 4 & & 8 \\
Latosol & 3 & 2 & 6 \\
Kambisol /Alluvial & 2 & & 4 \\
Regosol & 1 & & 2 \\
\hline
\end{tabular}

\subsubsection{Geology}

Rating of geology refers to Sigit and Paimin. Condition of geology consists of Andesite, Breccias, Limestone \& sandstone, sediment rock mountain \& deposit, conglomerate, Colluvium, alluvial (Sigit, 2016; Paimin et al., 2010:). The highest score is 15 and lowest score is 3 .

Table 5. Weighing and scoring of geology

\begin{tabular}{lccc}
\hline \multicolumn{1}{c}{ Geology } & Value & Weight & Score \\
\hline Andesite & 5 & & 15 \\
Breccias & 4 & & 12 \\
Limestone / Sandstone & 3 & 3 & 9 \\
Sediment Rock Mountain \& & 2 & & 6 \\
Deposit, Conglomerate, & 1 & 3 \\
Colluvium, Alluvial & & & 3 \\
\hline
\end{tabular}

\subsubsection{Location Height}

Location height is classified into 5 criteria, namely: low, rather low, medium, high, and very high (Ariyora et al., 2015). The highest score is 20 and lowest score is 4 .

Table 6. Weighing and scoring of location height

\begin{tabular}{cccc}
\hline Location Height $(\mathrm{m})$ & Value & Weight & Score \\
\hline$<12$ & 5 & & 20 \\
$>12-50$ & 3 & & 12 \\
$>50-75$ & 2 & 4 & 8 \\
$>75-100$ & 1 & & 4 \\
$>100$ & 1 & & 4 \\
\hline
\end{tabular}

\subsubsection{River Buffer}

River buffer is classified into three distances, namely: 25 meters, 50 meters and 100 meters. The highest score is 25 and the lowest score is 5 . 
A.Ardiansyah and Dyah Respati Suryo Sumunar / GEOSI Vol 5 No 1 (2020) 47-64

Table 7. Weighing and scoring of river buffer

\begin{tabular}{ccccc}
\hline Distance $(\mathrm{m})$ & Criteria & Value & Weight & Score \\
\hline $0-25$ & Close & 5 & & 25 \\
$>25-100$ & Medium & 3 & 5 & 15 \\
$>100-500$ & Far & 1 & & 5 \\
\hline
\end{tabular}

The collected data were then quantified in parameters of the highest and lowest score or in flood vulnerability variable, which would be used further to find interval scores to classify flood vulnerability levels.

Table 8. Quantification of highest score and lowest score

\begin{tabular}{lcc}
\hline \multicolumn{1}{c}{ Variable } & Highest Score & Lowest Score \\
\hline Land Use & 15 & 3 \\
Slope Inclination & 25 & 5 \\
Rainfall & 20 & 4 \\
Soil Type & 10 & 2 \\
Geology & 15 & 3 \\
Location Height & 20 & 4 \\
River Buffer & 25 & 5 \\
\hline Total & 130 & 26 \\
\hline
\end{tabular}

Results of the highest score addition and lowest score of a flood vulnerability variable was thencalculated intervally as manuals of a flood vulnerability level classification. Vulnerability level was classified into three classes. Quantification of interval class classification was done by the following equation (Hermon, 2012:).

$$
\mathrm{I}=(\mathrm{c}-\mathrm{b}) / \mathrm{k}
$$

Where

$\mathrm{I}=$ class interval distance, $\mathrm{c}=$ total highest score, $\mathrm{b}=$ total lowest score and $\mathrm{k}=$ desirable class. Desirable class is classified into three classes, namely, high, medium and low. Obtainable interval is 35 .

Table 9. Classification of flood vulnerability class

\begin{tabular}{clc}
\hline Class & \multicolumn{1}{c}{ Interval Vulnerability } & Score \\
\hline I & High & $>96-130$ \\
II & Medium & $>61-96$ \\
III & Low & $26-61$ \\
\hline
\end{tabular}


A.Ardiansyah and Dyah Respati Suryo Sumunar / GEOSI Vol 5 No 1 (2020) 47-64

Processing of data used GIS software, Arcgis 10.3.1 with research flowchart (see the following flowchart)

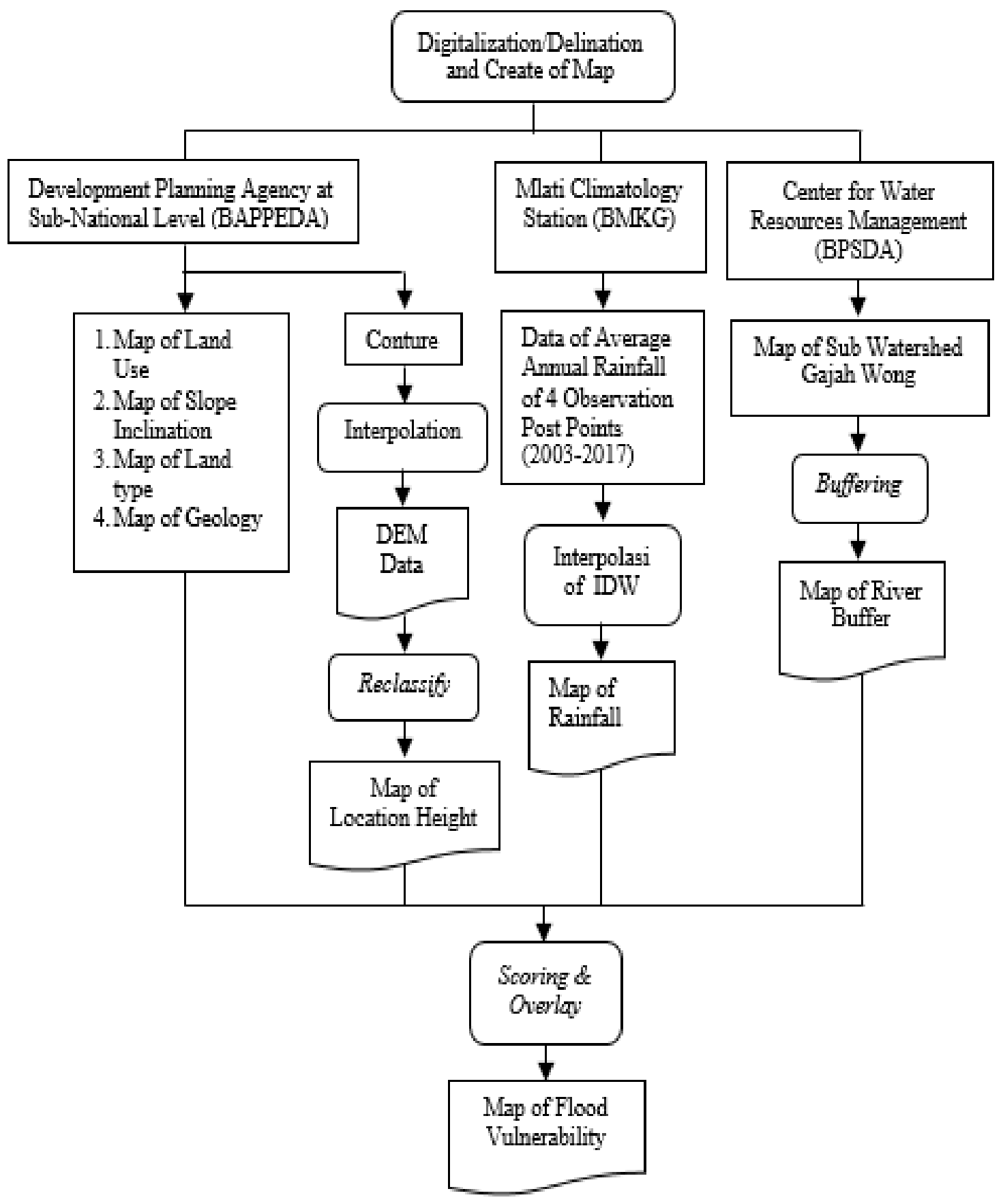

Figure 2. Flowchart of research 


\section{Results and Discussion}

\subsection{Parameters of Flood Vulnerability}

Gajah Wong Sub Watershed consists of 13 types of land-uses dominated by residences, wet fields and yards. The wider portion of land-uses are residences and irrigated fields, namely, 3,562.75 ha and 1,000.56 ha. The lowest land-uses are lakes/dams and conserved forests, reaching less than $1 \%$ of total area of Gajah Wong Sub Watershed.

The condition of slope inclination in Sub Gajah Wong Watershed was dominated by plain criteria with slope inclination interval of $0-8 \%$ having area of 4933.33 ha. Therefore, this conditionis categorised into high vulnerability because it becomes overflow target zone of rain water from highlands. Meanwhile, the sloped and waved criteria have very little portion, i.e. less than $0.1 \%$.

Data of rainfall were collected from Dadapan Gununganyar Observation Post, Ngaglik Observation Post, Sonayan Observation Post, Maguwoharjo observation post/Santan Observation Post, and SDA Potorono Observation Post, where these were distributed to some sub-districts. The results of interpolation indicated that distribution of average rainfall would tend to be low in direction of south and increase in northern direction leading to Merapi Mount. Dadapan Gununganyar Observation Post with averagely high rainfall reached 3,020 $\mathrm{mm} /$ year. While, the lowest rainfall was recorded in Observation Post of SDA Potorono, reaching $1873 \mathrm{~mm} /$ year, distributed to southern parts of Gajah Wong Sub Watershed.

Soil type in Gajah Wong Sub Watershed only consisted of Regosol and Kambisol. Entirely, Gajah Wong Sub Watershed was dominated by regosol soil type distributed to upstream zones of Merapi Mount zone directing to south, consisting of all Yogyakarta City zones and ending in downstream segment zones of Gajah Wong Sub Watershed, including Pleret sub-district. While, Kambisol soil type was distributed to eastern and western zones of Sleman district, and covering Bantul district.

Geological condition of Gajah Wong Sub Watershed was more dominated by rocks as a result of Volcano Mount deposits (Qmi), nearly reaching 99\% of total area of Gajah Wong Sub Watershed, and less structured by results of Old Volcano Mount Deposits (Qmo) located near Merapi Mount. Gajah Wong Sub Watershed location height was sufficiently varied ranging from $>12 \mathrm{~m}^{2}$ to $>100 \mathrm{~m}^{2}$. The location height of more than $100 \mathrm{~m}^{2}$ has the highest area reaching $61.94 \%$ of total area of Watershed. while height $>12-50 \mathrm{~m}^{2}$ has the lowest area reaching $0.51 \%$.

Based on the results of river buffer analysis, $44.64 \%$ of the area has a distance from river of $500 \mathrm{~m}^{2}, 9.12 \%$ area has $100 \mathrm{~m}^{2}$ distance from the river.. While zonal areas consisting 
A.Ardiansyah and Dyah Respati Suryo Sumunar / GEOSI Vol 5 No 1 (2020) 47-64

of the distance of $25 \mathrm{~m}^{2}$ from river has area of only $2.30 \%$. Therefore, the farther the distance from river, thewider the coverage.

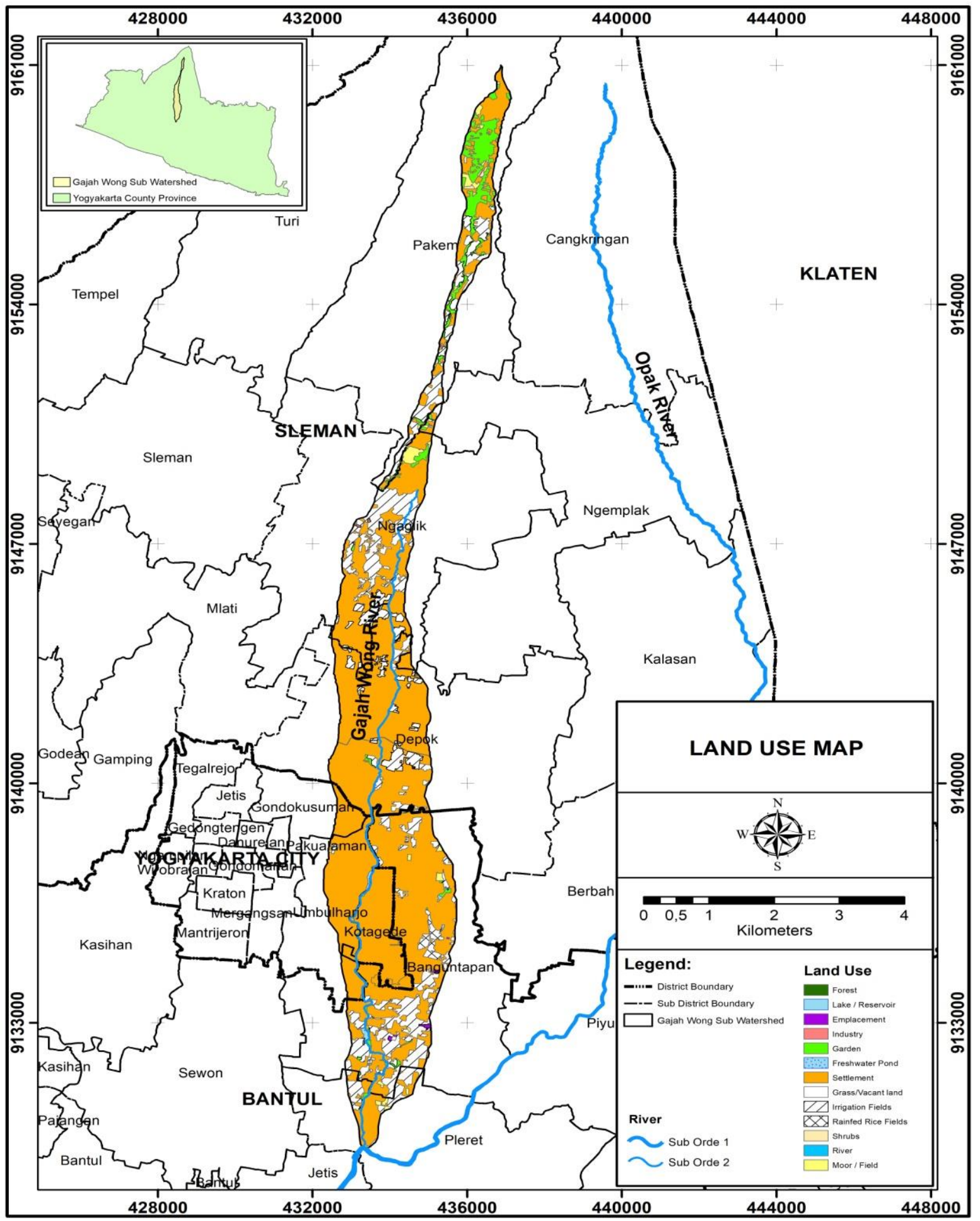

Figure 3. Map of land-uses in Gajah Wong sub watershed 


\subsection{Flood Vulnerability}

All parameters of flood vulnerability were analysed by overlay to gain end scores aiming at determining vulnerability and distribution intervals. Flood vulnerability intervals are more dominated by medium, low and high intervals of flood vulnerability occupy smaller portion. Low vulnerability has area of 338.34 ha, reaching $6.86 \%$ and medium vulnerability has area of 4,595.62 ha, reaching $93.13 \%$ and high vulnerability only has 0.76 has, reaching $0.02 \%$. These cases were caused by data of ecologic vulnerability parameters of Gajah Wong Sub Watershed, having less varying scores and criteria, such as, data of slope inclination, soil type, geology and location height. Therefore, these were dominated by medium vulnerability criteria.

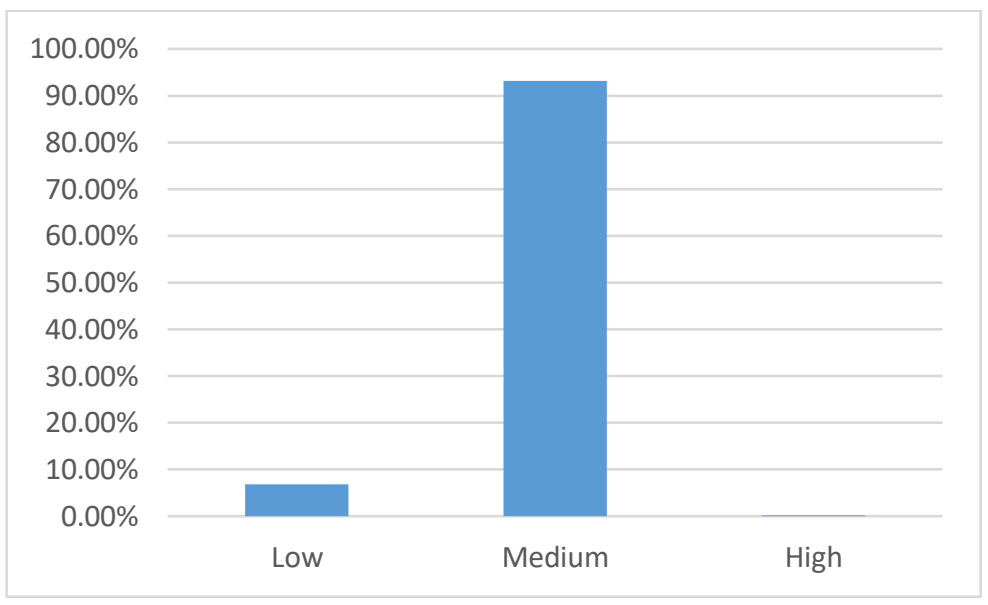

Figure 4. Percentage of flood vulnerability intervals

The results of analysis indicate that distribution of low flood vulnerability intervals seemed random, covering all administrative areas of Gajah Wong Sub Watershed, having smaller area than medium flood vulnerability intervals. Low flood vulnerability intervals were dominated by sub-district of Banguntapan which is the Ishoyet zone of IDW interpolation for rainfall data. The medium flood vulnerability intervals were more dominated by all zones of Gajah Wong Sub Watershed starting from upstream zone to downstream zone. Meanwhile, the high flood vulnerability intervals were distributed to Pleret sub-district being zone of river buffer analysis results in distance from 0 to $25 \mathrm{~m}^{2}$ and in location height scope ranging from $>12$ to $50 \mathrm{~m}^{2}$. 


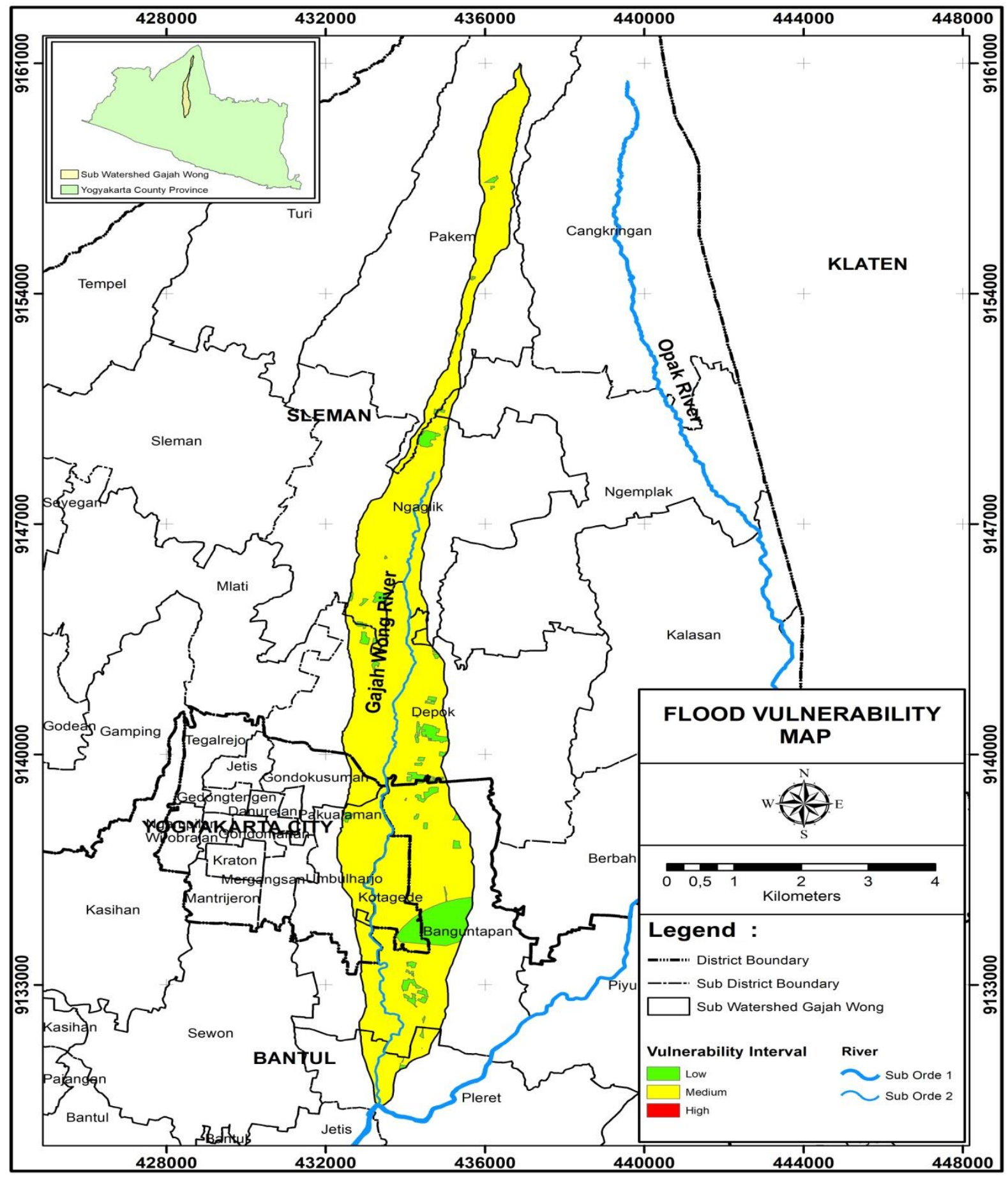

Figure 5. Map of flood vulnerability in sub watershed gajah wong

The result of flood susceptibility mapping above is obtained from an overlay analysis of attribute data of flood susceptibility parameters. Those attribute data consist of land use, slope tilt, rainfall, soil type, geology, altitude, and river buffer. The utilisationof those parameters is in accordance with the provisions of the analysis of BNPB regulation no 12 of 2012 which has been modified. 
In general, those analysis result shows that middle level of susceptibility is more dominating while the high level of susceptibility is only about the meeting area of the Gajah Wong River and Opak River. This condition is affected by the existence of Mount Merapi and the slope tilt so that rainwater runoff tends to dominate to the southward towards the downstream area. In this case, the flood tends to be dominated by submission flood. The middle and the downstream area are more impacted so that the water quality in the downstream is stained as the case in Umbulharjo sub-district which was marked with the increasing of E.Coli bacteria parameter (Winata \& Haryanto, 2013). To date, the slums that are susceptible to flooding are still found along the Gajah Wong River because they live in the lowland and it is close to the river (Ropingi, 2004). The flood may hit the residential area around Papringan Village, Catur Tunggal.

The rainfall area also shows the significant influence such as in the Banguntapan area which has a low average of rainfall. To date, based on the result of the observation, the government only issued the stroke policy in form of increasing and broadening embankment and also building the green open space to prevent the flood from hitting the residential area (Rachmawati \& Budiarti, 2017). Other mitigation efforts had also been implemented even though it was not yet optimum.

The preventive action is needed to decrease the futureimpacts. Flood mitigation and not - structurally (Heryanti \& Kingma, 2012) through the organization empowerment and the local disaster communities such as Gajah Wong Care Community, Pokdarwis need to be maximised in terms of the budget and coordination (Ardiansyah, 2018) especially the people in the riverbank. Therefoe, people can adapt such as with the flood-like, the higher house, the boat owning, etc. (Thanvisitthpon, 2017). The synchronisation and synergy are needed by the local government policymakers because the true problem of flooding is complex and involves various aspects of the environment, social, legal, economic and cultural (Kodoatie, 2014).

This study has some limitations, hence it is necessary to add and update data, such as data of rainfall that only consists of rain average during 14 years, at least 20 to 30 years. Other disadvantages such as land use, slope of mountain, land type geology and height of location are data from 2016. Therefore, it should be updated to at least last year. DEM data used to make a map of location height is only sourced from contour interpolation, this data should be obtained through interpolation of height point based on the results of a direct field survey. Analysis of river buffer has also a weakness related to a strong generalisation. 
Analysis of buffer should be a buffer of vulnerability map issued by related institutions, however, limited availability of data is one of the obstacles in this study. People residing in side of Gajah Wong River need understanding on mitigation and readiness to deal with flood. Flood occurring annually will result in physical damages. Physical development is flood resistance dam, groundsill and dam needs checking to anticipatethenext flood disaster. Care for keeping and maintaining rivers is also necessary to create clean and good river zone.

Urban flooding can be effectively analysed using buffer analysis (Lyu et al., 2018). City centers are generally the areas with the highest flood hazard with the main parameters of land use (Abebe et al., 2018). Poverty level in an area affects flood vulnerability because it is related to the mindset and land ownership (Szewrański et al., 2018). The quality of buildings in urban areas affects flood vulnerability because it is associated with disaster risk reduction facilities in each house (Darabi et al., 2019). Flood vulnerability is related to the previous history of flooding in the nearest area and to consider the similarity of geographical characteristics of the region (Wang et al., 2019). This study differs from the previous ones in that it involves analyses relating to quarterly volcanic products and the influence of karst areas in the downstream watershed. The results of previous studies focused on land use, human behavior, and aspects of landform.

This study can be used to analyse other risks, hazards, and mitigation of flood in Gajah Wong Sub Watershed, aiming at minimising the scales of the next damage results by implementing structural and non-structuralmitigation activities .

\section{Conclusion}

Flood vulnerability level in Gajah Wong Sub Watershed consisted of three intervals, namely: high, medium, and low flood vulnerability intervals. The high flood vulnerability interval covered an area of 0.76 ha $(0.02 \%)$. The medium flood vulnerability interval covered an area of 4595.62 ha $(93.13 \%)$. The low flood vulnerability interval covered an area of 338.34 ha $(6.86 \%)$. The medium flood vulnerability interval was more dominated by distribution to zone of Gajah Wong Sub Watershed. The low flood vulnerability interval dominated the sub-district of Banguntapan. The high flood vulnerability interval occupied smaller area distributed to Pleret sub-district which was an area of river buffer analysis in distance from 0 to $25 \mathrm{~m}^{2}$. 


\section{Conflict of Interest}

The authors declare that there is no conflict of interest with any financial, personal, or other relationships with other people or organizations related to the material discussed in the article.

\section{References}

Abebe, Y., Kabir, G., \& Tesfamariam, S. (2018). Assessing urban areas vulnerability to pluvial flooding using GIS applications and bayesian belief network model. Journal of Cleaner Production, 174, 1629-1641. doi:10.1016/j.jclepro.2017.11.066

Ardiansyah, (2018) “Analisis Kerentanan dan Bahaya Banjir Sub Daerah Aliran Sungai Gajah Wong di Daerah Istimewa Yogyakarta dengan Sistem Informasi Geografis (SIG)," Universitas Negeri Yogyakarta, Thesis. Published

Ariyora, Y., Budisusanto, Y. and Prasasti. I. (2015). Pemanfaatan Data Penginderaan Jauh dan SIG untuk Analisa Banjir (Studi Kasus: Banjir Provinsi DKI Jakarta). Geoid, 10, 137-146.

Beevers, L., Walker, G., and Strathie A. (2016). A-systems approach to flood vulnerability. Civil Engineering and Environmental Systems, 33, 1-15.

BNPB. (2012). "Regulation of the Head of National Disaster Management Agency of the Republic of Indonesia Number 2 Year 2012 on General Guidance on Study of Disaster Risk.” BNPB, Jakarta, p. 62.

Christiawan, P.I., and Wesnawa. I.G.A. (2014). Geografi Bencana. Yogyakarta: Graha Ilmu.

Darabi, H., Choubin, B., Rahmati, O., Torabi Haghighi, A., Pradhan, B., \& Kløve, B. (2019). Urban flood risk mapping using the GARP and QUEST models: A comparative study of machine learning techniques. Journal of Hydrology, 569, 142-154.

Hartono, M.B. (2014). "Peran Masyarakat dan Pemerintah dalam Pengelolaan Air Limbah Domestik di Sub DAS Gajahwong," Universitas Gadjah Mada, Thesis, unpublished.

Hermon. D. (2012). Geografi Bencana Alam. Jakarta: Raja Grafindo Persada, 272.

Heryanti, D.N., and Kingma, N.C. (2012). "Community Based Approach To Assess Flood Risk Perception Along Code River,” Indones. J. Geogr., vol. 44, no. 2, pp. 134-149.

igović, L., Pamučar, D., Bajić, Z., \& Drobnjak, S. (2017). Application of GIS-interval rough AHP methodology for flood hazard mapping in urban areas. Water (Switzerland), 9(6) doi:10.3390/w9060360

Jia, B., Simonovic, S.P., Zhong, P., and Yu Z. (2016). A- Multi-Objective Best Compromise Decision Model for Real-Time Flood Mitigation Operations of Multi-Reservoir System. Water Resources Management, 30, 3363-3387.

Kourgialas, N.N., and Karatzas, G.P. (2016). A flood risk decision making approach for Mediterranean tree crops using GIS; climate change effects and flood-tolerant species. Environmental Science and Policy, 63, 132-142.

Lee, S., Kim, J. -., Jung, H. -., Lee, M. J., \& Lee, S. (2017). Spatial prediction of flood susceptibility using random-forest and boosted-tree models in seoul metropolitan city, 
korea. Geomatics, Natural Hazards and Risk, 8(2), 1185-1203. doi:10.1080/19475705.2017.1308971

Lyu, H. -., Sun, W. -., Shen, S. -., \& Arulrajah, A. (2018). Flood risk assessment in metro systems of mega-cities using a GIS-based modeling approach. Science of the Total Environment, 626, 1012-1025. doi:10.1016/j.scitotenv.2018.01.138

Manfré, L.A. (2012) An Analysis of Geospatial Technologies for Risk and Natural Disaster Management. ISPRS International Journal of Geo-Information 1, 166-185.

National Standardization Agency. (2010). Klasifikasi Penutup Lahan, Number. 7645:2010. Jakarta: BSN, 28.

Paimin, P., Sukresno, S., and Purwanto, P. (2010). Sidik Cepat Degradasi Sub DAS. Bogor: Research and Development Center for Conservation and Rehabilitation, Bogor Forestry Research and Development Agency.

Pettorelli, N., Laurance, W. F., O'Brien, T. G., Wegmann, M., Nagendra, H., \& Turner, W. (2014). Satellite remote sensing for applied ecologists: Opportunities and challenges. Journal of Applied Ecology, 51(4), 839-848. doi:10.1111/1365-2664.12261

Rachmawati R., and Budiarti C.V. (2017). "Use of Space and the Need for Planning in the Disaster-Prone Area of Code River, Yogyakarta, Indonesia," Indones. J. Geogr., vol. 48, no. 2, p. 178.

Ramdhan, S., Arifin, H.S., Suharnoto, Y. (2018)."Towards Water Sensitive City: Lesson Learned From Bogor Flood Hazard in 2017," International Conference On Energy, Environment And Information System, Semarang, Indonesia, vol. 31, pp. 1-5, February [E3S Web Conf. Indonesia, p. 05, 2017]

Robert J. K. (2014). Rekayasa Dan Manajemen Banjir Kota. Yogyakarta: Andi Offset.

Ropingi, R. (2004). "Perilaku Sosial Masyarakat Lembah Sungai Gajah Wong Yogyakarta," J. Penelit. dan Eval. Pendidik., vol. 6, no. 1, pp. 57-71.

Santillan, J.R., Marqueso, J.T., Makinano-Santillan, M. and Serviano, J.L. (2016). "Beyond flood hazard maps: Detailed flood characterization with remote sensing, gis and 2D modelling," in International Archives of the Photogrammetry, Remote Sensing and Spatial Information Sciences - ISPRS Archives, 2016, vol. 42, no. 4W1, pp. 315-323.

Sein, K.K., and Myint, T. (2016). Flood hazard mapping using hydraulic model and GIS : a case study in Mandalay city, Myanmar. Suan Sunandha Science and Technology Journal, 5, 15-20.

Sigit, A. (2016). "Analisis Spasial Kemampuan Infiltrasi Sebagai Bagian Dari Indikasi Bencana Kekeringan Hidrologis di DAS Wedi, Kabupaten Klaten-Boyolali," Proceedings of the 2016 National Geography Seminar UMS Disaster Risk Reduction Efforts Related to Climate Change, Surakarta, Indonesia, pp. 101-111.

Stoica, A. and Iancu, I. (2011). Flood vulnerability assesment based on mathematical modeling. Mathematical Modeling in Civil Engineering, 1, 265-272.

Subardja, D.S, Ritung, S., Anda M., Suryani E., and Subandiono R.E. (2014). Petunjuk Teknis Klasifikasi Tanah Nasional, 1st ed. Center for Agricultural Land Resources Research and Development Agency for Agricultural Research and Development, 45. 
A.Ardiansyah and Dyah Respati Suryo Sumunar / GEOSI Vol 5 No 1 (2020) 47-64

Suryantoro, A. (2009). Integrasi Aplikasi Sistem Informasi Geografis. Malang: Ombak, 214.

Szewrański, S., Świąder, M., Kazak, J. K., Tokarczyk-Dorociak, K., \& van Hoof, J. (2018). Socio-environmental vulnerability mapping for environmental and flood resilience assessment: The case of ageing and poverty in the city of wrocław, poland. Integrated Environmental Assessment and Management, 14(5), 592-597. doi:10.1002/ieam.4077

Tehrany, M. S., Pradhan, B., \& Jebur, M. N. (2014). Flood susceptibility mapping using a novel ensemble weights-of-evidence and support vector machine models in GIS. Journal of Hydrology, 512, 332-343. doi:10.1016/j.jhydrol.2014.03.008

Tehrany, M.S, Shabani, F., Neamah Jebur, M., Hong, H., Chen, W., \& Xie, X. (2017). GISbased spatial prediction of flood prone areas using standalone frequency ratio, logistic regression, weight of evidence and their ensemble techniques. Geomatics, Natural Hazards and Risk, 8(2), 1538-1561. doi:10.1080/19475705.2017.1362038

Thanvisitthpon, N. (2017). "Impacts of repetitive floods and satisfaction with flood relief efforts: A case study of the flood-prone districts in Thailand's Ayutthaya province," Clim. Risk Manag., vol. 18, pp. 15-20.

Tika, M.P. (2005). Metode Penelitian Geografi. Jakarta: Bumi Aksara, 162.

Wang, Y., Hong, H., Chen, W., Li, S., Pamučar, D., Gigović, L., . . . Duan, H. (2019). A hybrid GIS multi-criteria decision-making method for flood susceptibility mapping at shangyou, china. Remote Sensing, 11(1) doi:10.3390/rs11010062

Weng, Q. (2010). Remote Sensing and GIS Integration. New York: The McGraw-Hill Companies.

Winata, E., and Hartantyo, E. (2013). "Kualitas Air Tanah di Sepanjang Kali Wong Ditinjau dari Pola Sebaran Eschericjia Coli (Studi Kasus Kecamatan Umbulharjo)," J. Fis. Ilm., vol. XVII, no. Tabel 1, pp. 8-11. 